\title{
Development of Learning Media with the STEM Approach on Materials of Sequences and Series
}

\author{
Lika Aryati, Heni Pujiastuti (*), Ria Sudiana \\ Universitas Sultan Ageng Tirtayasa, Jl. Raya Jakarta KM.4, Panancangan, Kec. Serang, \\ Kota Serang, Banten 42124, (0254) 280330, Indonesia
}

Received: May 15, 2020

Revised: August 16, 2020

Accepted: August 31, 2020

\begin{abstract}
This research aims to develop of learning media with stem approach on materials of sequences and series which is valid and practice as well as have the potential effects of learning media. This research is the development of types of design research type development study which consists of two main stages namely the preliminary stage and the formative evaluation stage. The research subject is students of class XI IPA 4 SMA Negeri 4 Tangerang Regency which amounts to 36 students. Based on the results of the study, obtained that that the learning media with the STEM approach on materials of sequences and series is feasible for use in learning activities in learning activities based on test of validity, practicality and potential effects. The validity of the learning media developed is obtained at the stage of the review expert. The practicality of the learning media developed is obtained at the stages of the one-to-one and small group. The potential effects of the learning media seen from the response of students to instructional media at the stage of field test stage which get the percentage amounted to $87 \%$ with very good category. So learning media with the STEM approach to sequences and series materials is feasible and practical for use in learning activities as well as having a potential effect on student responses.
\end{abstract}

Keywords: Learning Media, STEM, Sequence and Series.

(*) Corresponding Author: $\quad$ henipujiastuti@untirta.ac.id, 087821320371

How to Cite: Aryati, L., et al. (2020). Development of learning media with the STEM approach on materials of sequences and series. Formatif: Jurnal Ilmiah Pendidikan MIPA, 10 (2), 91-102. http://dx.doi.org/10.30998/formatif.v10i2.6400

\section{INTRODUCTION}

The development of the times has entered into the era of the revolution of industry 4.0 requires the development of a country to be able to compete in a modern where the field of information technology and science are experiencing a lot of progress. Progress in the field of technology and science this oblige every human to be always ready in developing their competences as well as can innovate with the capabilities they have so that the availability of human resources capable to develop the nation and the state. Education is a main pillar on which to develop quality human resources, creative, and critical thinking in developing nations and countries, but the quality od education is still not in accordance with expectations (Leonard \& Wibawa, 2020) in order to answer the challenges of the times in the era of the 21 st century. In this globalization era, where increasing competition demands a skill and professionalism in various aspects of life owned by human resources.

National Science Teachers Association or NSTA (2011) states that the various skills there on the 21st century such as problem solving skills and critical thinking skills can be developed in the world of education. STEM (Science, Technology, Engineering, and Mathematics) including the rumors that important in the world of education that exists at 
this time (Becker \& Park, 2011). The National Science Foundation of the United States (U.S.) launched the term STEM for the first time in the 1990s as a theme of the reform movement in education (Hanover, 2011). Gonzalez \& J.Kuenzi (2012) states that the STEM has a meaning that is a teaching and learning related to the field of science, technology, engineering and mathematics. Bybee (2013) says that STEM learning is reform from the development of education as the theme of the reform movement of education which is the solution of the challenges of the 21st century in many developed countries such as the United States. Beers (2011) says that STEM learning is a combination of learning science, technology, engineering and math that can help the success of the $21 \mathrm{st}$ century skills.

Based on the National STEM Education Center STEM education means providing reinforcement of educational practice in the field-the field of the disciplines of STEM, and develop educational approaches that unite the fields of the disciplines of STEM with a focus on solving problems that are concrete in everyday life (Rustaman, 2016). STEM with education approach is defined as an important concept in the 21st century to develop knowledge, skills and beliefs about subjects with an interdisciplinary approach (Corlu, Capraro, \& Capraro, 2014). STEM in learning in mathematics has a role in forming a learning goal which has so far made mathematics only as a theory which ultimately plays a role as an effective solution that can be interpreted in everyday life as a form of creating and developing mathematical knowledge that has been obtained by the student. A learning that presents a surreal environment that is directly experienced by the students in the form of daily activities can be realized if the STEM is associated directly with the environment (Subramaniam et al., 2012).

STEM has also taken a central role in the projects implemented in developed Countries one of them is Turkey, where the project aims to improve the knowledge and technical skills with the use of the concept of science. For example, a study conducted in Turkey revealed that activities that emphasize the engineering design process help teachers and students improve their engineering and science processes and skills. STEM-based education aims to produce students who are skilled in developing various skills possessed and able to apply them in various problems and situations encountered in daily life when involved in a community environment where these goals are in line with the learning paradigm of the 21st Century (Mayasari, Kadarohman, \& Rusdiana, 2014).

Permendikbud number 37 of 2018 about curriculum changes on the 2013 curriculum where students at elementary, middle and high school levels receiving the lessons of informatics, where it is sufficient to support STEM education for entry therein. The general steps of the STEM approach proposed by Billstein \& Williamson (2007) contained in student activities includ setting the stage, exploration, key concept, dan practice and application exercise.

The development of Information and Communication Technology (ICT) many changed various aspects of human life including in education. The influence of technology that is very fast can not be avoided in the world of education. The role of Information and communication technology in the learning process can be used as a medium of learning. Learning Media has an important position in the process of learning and teaching. Simanjuntak (2013) argue that the lecture, discussion, laboratory practice and field visits are still relied upon by educators. Because of this, the utilization of Information and Communication Technology (ICT) is becoming demands in the curriculum 2013.

According to Hamalik (Arsyad, 2010) that the use of instructional media in the teaching and learning process can foster interest, motivation and stimulation in the learning activities, and provide the psychological impact on students. One of learning media which are widely used and utilized by the teachers is cellular technology and smartphone devices by using a learning model that elevates from the development of cellular technology and 
smarthphone itself, namely mobile learning. According to Hasan (in Musahrain, Suryani, \& Suharno, 2017), the use of mobile learning in the learning activities in the classroom has three main functions, namely as a supplement, complement or substitution.

According to Simon (2004), mobile learning is cellular learning as the acquisition of knowledge and skills through the use of cellular technology done anywhere, anytime, and produce changes in behavior. This learning generally uses an Android application device that is easy to operate and many are owned by any person. Android can be used as one alternative in the process of learning because it can do a learning anytime and anywhere. But the ability of educators who have not adequate to be able to produce media as well as product-based learning Information and Communication Technology into the problems in learning at this time. Simanjuntak (2013) argue that the lecture, discussion, laboratory practice and field visits are still relied upon by educators.

Sequences and series is one of the materials in mathematics lessons students studied at the level of High School or Vocational School degree. The results of research conducted by McDonald, Mathews, \& Strobel (2000), sequences and series is one of the materials in calculus where each students often experiences misunderstanding. The results of other research carried out by Nurdin (2012) stressed that in the concept of sequence learning, most students just memorize the formula. Therefore it will be developed media approaches to the study of STEM material on sequences and series.

\section{METHODS}

This research is the development of types of design research type development study which consists of two main stages namely the preliminary stage and the stage of formative evaluation that include self evaluation, expert review and one-to-one, small group and field tests (Tessmer, 1993; Zulkardi, 2006). The subject of the research is 36 students of class XI IPA 4 SMA Negeri 4 Tangerang Regency.

At the preliminary stage, the first stage to be performed is to determine the place as well as the subject of research. Furthermore, researchers will analyze and design. On the stage of the analyze, the researchers conducted the analysis of students and analysis of the curriculum in accordance with the 2013 curriculum, material analysis, and analysis of the basic competence. At the stage of designing, the researcher designed the instructional media to be developed.

At the stage of formative evaluation, the first stage of carried out is the self evaluation where the researcher will conduct a own assessment against the design of instructional media to be developed. Researchers look back on the suitability of the measures of the STEM on the activities of students who are in the learning media with characteristics of STEM PjBL. From this stage the obtained learning media prototype 1. At the expert review stage, prototype 1 learning media will be tested on the education experts and media experts. The results of the evaluation given by experts will be used as consideration to revise the learning media prototype 1 .

Learning Media prototype 1 are also given at the stages of one-to-one which will be tested to some students. Then students are asked to provide comments and responses regarding the learning media prototype 1 . The comments and suggestions obtained from this stage will be used as consideration to revise the instructional media prototype 1 . While the results of the questionnaire will be used to see the practicality of the developed learning media.

Learning Media prototype 2 is the result of a revision of the learning media prototype 1 which will then be given on the stages of small group which will be tested to some students who are asked to use the learning media as well as provide responses in the form 
of comments and suggestions to the learning media prototype 2 to see the practicality of the developed learning media where the results of the practicality at this stage will be merged with the results of the practicality of the obtained at the stage of one-to-one. Comments and suggestions obtained from this stage will be used as consideration to revise prototype 2 .

The results of the revision of the learning media prototype 2 is the learning media prototype 3 which will be given on the stages of the field test. On the stages of the field test, learning media prototype 3 tested on the subject of the study to see the potential effects of the developed learning media to the response of the students after using the learning media.

Data collection techniques in this research is a questionnaire. According to Arikunto (2006), a questionnaire is a collection of some of the questions used with the aim of obtaining information from the respondents to know the things that want to be known by the researchers or the personal data of the respondents in writing. The questionnaire in this research will be used to obtain the validity and practicality of the learning media obtained from the expert test education, test media experts as well as students' response as a test of the practicality and the response of the students to see the potential effects of the learning media.

Widoyoko (2010, p. 58) says that the research instrument is a tool used with how to perform measurements to collect research data. The instrument used by the researcher in collecting data that will be used in the research process. Instruments in the collection of data that will be used in the research is a questionnaire consists of questionnaire validation of the education experts, a questionnaire validation media experts, questionnaires practicality of students, and student questionnaire responses.

There are three types of data analysis in this study, namely the analysis of validity, practicality and potential effects. Analysis of validity will be obtained from the results of the charging questionnaire by education experts and media experts who performed on the stages of expert review. Analysis of practicality obtained from the results of the charging questionnaire responses of students on the stages of the one-to-one and the stages of small group. While the analysis of the potential effects derived from the results of the charging questionnaire responses of students on the stages of the field test. The Data is then analyzed to determine the validity, practicality as well as potential effects of media approaches to the study of STEM material on sequences and series.

\section{RESULTS \& DISCUSSION}

\section{Results}

\section{Premilinary Stage}

On the stage of the premilinary that is doing the analysis of the students with the aim to find out the number of students who will be the subject in the study. Furthermore, researchers will design. At the stage of designing, the researcher designed the learning media with the STEM approach on material of sequences and series. In addition to designing learning media, researchers also collect materials about the material of sequences and series derived from textbooks mathematics 2013 curriculum revision 2017. Then researchers designed activities the students by using the steps STEM the PjBL and connect it with the material of sequences and series. As well as create the questions that will be used for the evaluation. The result from designing this will then enter the stage of self evaluation which will then become the learning media prototype 1 . The initial design can be seen in Figure 1. 


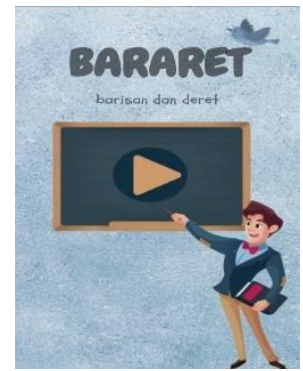

Figure 1. The Initial Design of The Learning Media

\section{Formative Evaluation Stage}

\section{Self Evaluation}

At this stage, researchers conduct an assessment of the developed learning media with the assistance of the supervisors. Researchers look back at the steps of the STEM on the activities of students who are in the learning media in accordance with the characteristics of STEM PjBL as well as the design, contents and every placement contained in the learning media. After self evaluation, there are some improvements of the words, there are still typo and some comments and suggestions from the supervisor to do the revision. After doing the revision, then obtained learning media prototype 1 ready to be piloted in the next stage.

\section{Expert Review}

At the stage of expert review involves some expert as a validator which is divided into 2 namely education experts and media experts, namely :

a) Education Experts

Education experts do the validity to see the validity of the developed learning media in terms of aspects of content and language. Learning Media was tested by three lecturers of Mathematics Education University of Sultan Ageng Tirtayasan with the field of expertise of Educational experts. The results of the third appraisal expert education can be seen in Table 1 .

Tabel 1. The Results of The Validity of Education Experts

\begin{tabular}{cccccc}
\hline \multirow{2}{*}{ No } & Aspects & $\begin{array}{c}\text { Total } \\
\text { Score }\end{array}$ & $\begin{array}{c}\text { Max } \\
\text { Score }\end{array}$ & Percentage & Description \\
\hline 1. & Content & 77 & 90 & $86 \%$ & Very valid \\
2. & Language & 56 & 60 & $93 \%$ & Very valid \\
\hline \multicolumn{2}{l}{ Total } & 133 & 150 & $89 \%$ & Very valid \\
\hline
\end{tabular}

b) Media Experts

Media experts do the validity to see the validity of the developed learning media in terms of aspects of the presentation, effectiveness and graphics. Learning Media was tested by three lecturers with expertise media experts. The results of the assessment of the third media experts can be seen in Table 2 .

Table 2. The Results of The Validity of Media Experts

\begin{tabular}{cccccc}
\hline \multirow{2}{*}{ No } & \multirow{2}{*}{ Aspects } & $\begin{array}{c}\text { Total } \\
\text { Score }\end{array}$ & $\begin{array}{c}\text { Max } \\
\text { Score }\end{array}$ & Percentage & Description \\
\hline 1. & Presentation & 80 & 90 & $89 \%$ & Very valid \\
2. & Effectiveness & 26 & 30 & $87 \%$ & Very valid \\
3. & Graphics & 51 & 60 & $85 \%$ & Quite valid \\
\hline & Total & 157 & 180 & $87 \%$ & Very valid \\
\hline
\end{tabular}




\section{One-to-one}

The researchers also conducted validation on the stages of the one-to-one process simultaneously with the stages of expert review. At this stage, researchers perform a test of the practicality of learning media prototype 1 that were tested to three high School students. The results of the practicality of the student response the stages of one-to-one can be seen in Table 3.

Table 3. The Results of The Student Response The Stages of One-To-One

\begin{tabular}{cccccc}
\hline \multirow{2}{*}{ No } & Aspects & $\begin{array}{c}\text { Total } \\
\text { Score }\end{array}$ & $\begin{array}{c}\text { Max } \\
\text { Score }\end{array}$ & Percentage & Description \\
\hline 1 & Usefullness & 39 & 45 & $87 \%$ & Very Practical \\
2 & Ease of Use & 68 & 75 & $91 \%$ & Very Practical \\
3 & Satisfaction & 50 & 60 & $83 \%$ & Very Practical \\
\hline & Total & 157 & 180 & $87 \%$ & Very Practical \\
\hline
\end{tabular}

\section{Revision Media Learning Prototype 1}

Revisions made to the learning media prototype 1 based on the comments and suggestions given by educational experts and media experts on the stages of expert review as well as comments and suggestions given by the students on the stages of the one-to-one. The results of the revision of the learning media prototype 1 is called the learning media prototype 2. Following is one of ther revisions from the media experts, education experts and students on the stages of the one-to-one against the media learning prototype 1 can be seen in Table 4.

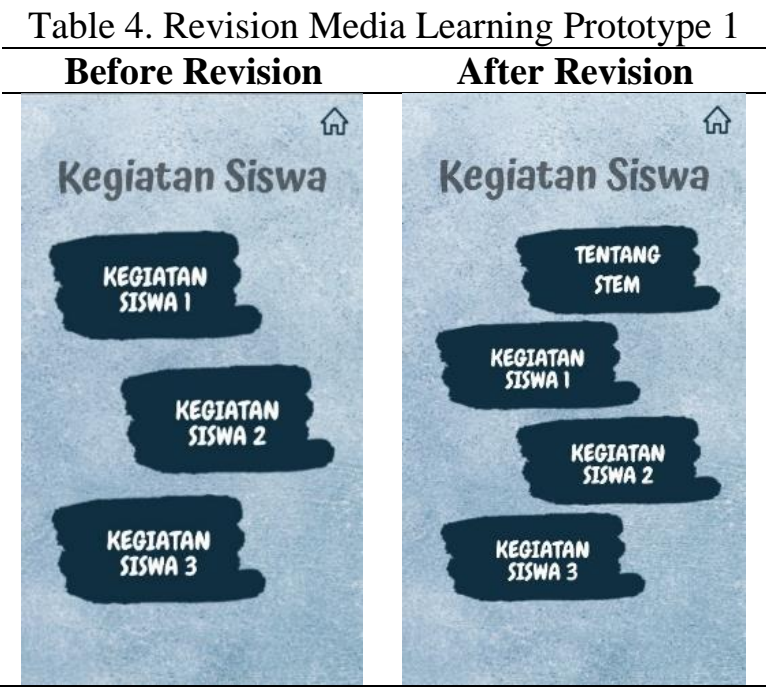

\section{Small Group}

At this stage, the researchers tested the prototype 2 learning media to six high school students. The six students were asked to try to download the application from the link which has been given as well as use the app, then work the evaluation questions contained in the application with the quiz code that has previously been given to the students. The results of the practicality of the student response the stages of one-to-one can be seen in Table 5 . 
Table 5. The Results of The Student Response The Stages of Small Group

\begin{tabular}{cccccc}
\hline \multirow{2}{*}{ No } & \multirow{2}{*}{ Aspects } & $\begin{array}{c}\text { Total } \\
\text { Score }\end{array}$ & $\begin{array}{c}\text { Max } \\
\text { Score }\end{array}$ & Percentage & Description \\
\hline 1 & Usefullness & 80 & 90 & $89 \%$ & Very Practical \\
2 & Ease of Use & 137 & 150 & $91 \%$ & Very Practical \\
3 & Satisfaction & 102 & 120 & $85 \%$ & Very Practical \\
\hline & Total & 319 & 360 & $89 \%$ & Very Practical \\
\hline
\end{tabular}

\section{Revision Media Learning Prototype 2}

Revisions made to the learning media prototype 2 based on the comments and suggestions that have been given students on the stages of small group. The results of the revision of the learning media prototype 2 called the learning media prototype 3 . Learning Media prototype 3 which will then be used for testing on the stages of the field test. As for the revision done this is to add examples of questions from the previous one only one example of matter in each material of sequences and series being three examples of matter in each material of sequences and series.

\section{Field Test}

Having obtained the learning media prototype 3 are valid and practical, then carried out the experiment at the stage of field test. This stage is the last stage in the stages of formative evaluation in developing a learning media with the approach of STEM material on sequences and series. At this stage, the prototype 3 will be tested to the subject of research is students of class XI IPA 4 SMA Negeri 4 Tangerang Regency which consists of 36 students to determine the potential effects on the response of the students of the developed learning media. At this stage students are given a questionnaire about the students ' response to learning media prototype 3 they have use. The results of the questionnaire responses of the students on the stages of the field test of this can be seen in Table 6.

Table 6. The Results of The Student Response The Stages of The Field Test

\begin{tabular}{cccccc}
\hline \multirow{2}{*}{ No } & \multirow{2}{*}{ Aspects } & $\begin{array}{c}\text { Total } \\
\text { Score }\end{array}$ & $\begin{array}{c}\text { Max } \\
\text { Score }\end{array}$ & Percentage & Description \\
\hline 1 & Usefullness & 466 & 540 & $86 \%$ & Very Good \\
2 & Ease of Use & 780 & 900 & $87 \%$ & Very Good \\
3 & Satisfaction & 628 & 720 & $87 \%$ & Very Good \\
\hline & Total & 1874 & 2160 & $87 \%$ & Very Good \\
\hline
\end{tabular}

\section{Discussion}

At the preliminary stage is to analyze the student that will be used, namely the students of class XI Upper Secondary School as a subject in research. Furthermore, researchers analyze the curriculum used in schools, namely curriculum 2013 revised 2017. Material on sequences and series there are 2 Basic Competencies of 3.6 Generalize the pattern number and the number in the arithmetic sequence and geometry, and 4.6 Using the pattern of the arithmetic sequence geometry and to present a contextual problem (including growth, decay, compound interest and annuity). Furthermore, researchers do the designing for learning media that will be developed. At the stage of designing, the researcher designed the layout of the media approaches to the study of STEM material on sequences and series. At this stage also made the questionnaire the validation of the education experts, a questionnaire validation media experts, questionnaires practicality of the students as well as questionnaire responses of students. 
The next stage is the stage of formative evaluation which includes the stages of self evaluation, expert review and one-to-one, small group and field test. On the stages of the self evaluation, researchers conduct an assessment of the developed learning media with the assistance of the supervisor. Look back on the steps of the STEM on the activities of students who are contained in the learning media in accordance with the characteristics of STEM PjBL as well as the design, contents and every placement contained in the learning media. The supervisor also gave suggestions and comments to make improvements. From this stage the obtained learning media prototype 1 will be tested to the stages of expert review and one-to-one.

On the stages of expert review, learning media prototype 1 was tested to the education experts and media experts to determine the validity of the learning media prototype 1. Validation is conducted by three educational experts carried out against aspects of the content and aspects of the language used in the learning media prototype 1 . The overall learning media prototype 1 to get the percentage of the validity of expert education by $89 \%$ and are included in the category of very valid. There is also a validation is conducted by three media experts. Validation is conducted consists of three aspects, namely the presentation, the effectiveness and the graphics overall to get a percentage of the validity of $87 \%$ included in the category of very valid.

At the stage of expert review in addition to providing validation, education experts and media experts also gave comments and suggestions for learning media prototype 1 . Suggestions and comments given by the expert will be used as the material to revise for the media learning prototype 1. Learning Media prototype 1 are also tested on the stages of the one-to-one At this stage, test the practicality of learning media prototype 1 that were tested to three high School students. Overall media approaches to the study of STEM material on sequences and series which is developed to get a percentage of $87 \%$ with the category of very practical.

At this stage students are also asked to provide feedback in the form of comments and suggestions regarding the learning media prototype 1 . Comments and advice given to students will be used as material to revise the learning media prototype 1. Furthermore, to see the practicality of learning media with the approach of STEM material on sequences and series which is developed, then the percentage of the practicality of the obtained at this stage will be combined with the percentage of the practicality on the stages of small group who will then get the average percentage of the practicality of stages of one-to-one and the stages of small group. Learning Media prototype 1 which have been revised in accordance with the suggestions and comments obtained from the stages of expert review and one-toone will become the learning media for prototype 2 which are then used for testing on the stages of small group.

Small group is the third stage of the stage of the formative evaluation. At this stage, test the practicality of learning media prototype 2 tested on six high School students. Overall media approaches to the study of STEM material on sequences and series which is developed to get a percentage of $87 \%$ with the category of very practical.

Furthermore, to see the practicality of learning media with the approach of STEM material on sequences and series which is developed, then the percentage of the practicality of the obtained at this stage will be combined with the percentage of the practicality on the stage of one-to-one then will get the average percentage of the practicality of stages of oneto-one and the stages of small group.

At this stage students are also asked to provide feedback in the form of comments and suggestions regarding the learning media prototype 2 . Comments and suggestions from students will be used as material to revise the learning media prototype 2. Learning Media prototype 2 has been revised in accordance with the suggestions and comments obtained 
from the stages of small group becomes learning media prototype 3 which is then used for testing on the stages of the field test.

The final stage is the stages of the field test. The stages of the field test done to the 36 students of class XI IPA 4 SMA Negeri 4 Tangerang Regency on April 14, 2020. At this stage will be seen the effect of potential on the response of the students. Students are given a link to download the app Bararet first and than install the application Bararet on their smartphones. There are no obstacles for students to download and install the application. Once the application is installed, students try to use the application Bararet and given the code to do the evaluation contained in the application. The Constraints arise when students wish to do the evaluation, because the evaluation using the platform Quizizz there are some students who have the problems when logging into the Quizizz because of the constrained network internet slow as well as at the time of going to the platform Quizizz was a bit hampered. But the problems that occur do not last long and all students can complete the evaluation. After doing the evaluation, students are given links to the google form to fill in the questionnaire students ' response to the application Bararet. In the student questionnaire responses also contained comments regarding the application Bararet they have to fill. Overall, based on the results of the questionnaire responses of students towards learning media get a percentage of $87 \%$ and is included in the very good category. The results of the student questionnaire responses can be seen in Figure 2.

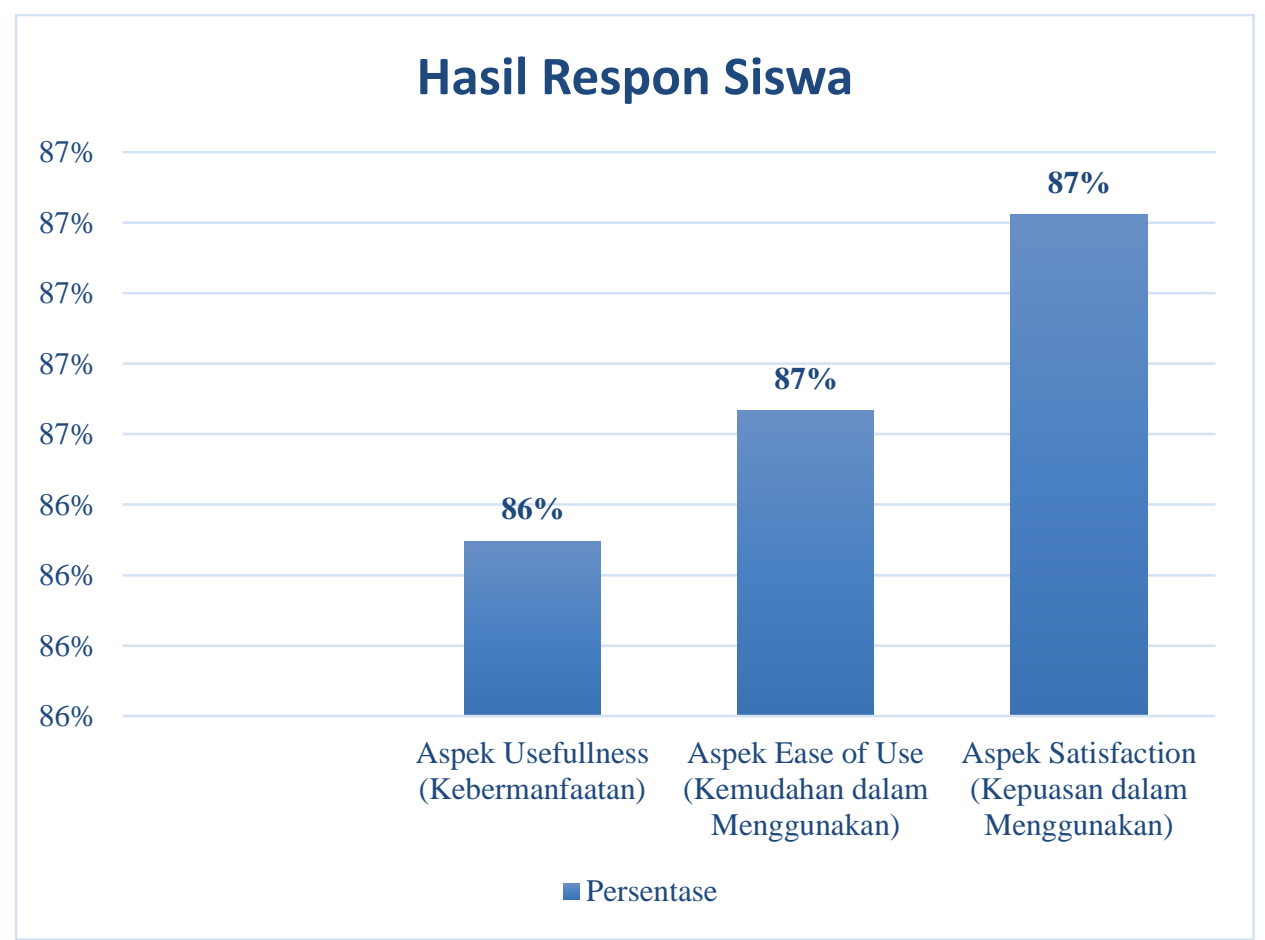

Figure 2. The Results Of The Response Of The Students

Learning media with the STEM approach on material of sequences and series which is developed named Bararet categorized very valid based on the results of testing conducted by the education experts and media experts, in addition students also stated that learning media is practical for use in learning activities and based on the comments given, students feel happy and love learning media Bararet in the learning activities. In addition learning media Bararet also has the effect of a potentially very good on the response of the students.

The results of this study are in line with some of the research that has been done by Nessa, Hartono, \& Hiltrimartin (2017) that produce books student-based STEM Problem- 
Based Learning a valid, practical and have the potential effects, research conducted by Utami, Jatmiko, \& Suherman (2018) that produces the modules mathematical approach to Science, Technology, Engineering, and Mathematics (STEM) on the material quadrilateral valid, worthy and interesting, as well as research conducted by Irmita (2018) that produce learning modules chemical approach to STEM in the material of chemical equilibrium are valid and the response of the students with very good category. However, if the third study develop books and modules that physically, this research is to develop learning media shaped the application.

The excess of the media approaches to the study of STEM material on sequences and series that have been developed, namely, learning media shaped the app that can be downloaded by students so that students can learn anywhere and anytime where it is in line with the understanding put forward by Simon (2004) where learning is mobile as the acquisition of knowledge and skills through the use of mobile technology that can be done anywhere and anytime, then have the availability of the music in the app which makes the students not feel bored while learning coupled with student activities that can be downloaded by students. However the media approaches to the study of STEM material on sequences and series that have been developed have several shortcomings, including applications can only be downloaded by users of the android platform course, the material contained in the application only the material sequences and series.

\section{CONCLUSION}

This study produce learning media with the approach of STEM material on sequences and series which are very valid and very practical to use in the learning activities of mathematics. The validity of the learning media obtained based on the results of the test of the education experts and test experts the media on the stages of expert review. The practicality of learning media obtained based on the response of the students on the stages of the one-to-one and small group. Learning media with the STEM approach on materials of sequences and series which is developed also has potential effects against the response of the students on the stages of the field test. So the learning media with the STEM approach on materials of sequences and series which is developed is feasible for use in the mathematics learning activity because it has met the indicators the validity of which is very valid, indicator of the practicality of that is very practical as well as indicators of the potential effects are very good.

\section{REFERENCES}

Arikunto, S. (2013). Dasar-Dasar Evaluasi Pendidikan (Revised Edition). Jakarta: PT Bumi Aksara.

Becker, K., \& Park, K. (2011). Effects of integrative approaches among science, technology, engineering, and mathematics (STEM) subjects on students' learning: A preliminary meta-analysis. Journal of STEM Education: Innovations \& Research, 12 (5), 23-37.

Beers, S. (2011). 21st Century Skills: Preparing Students for Their Future. Accessed from http://www.yinghuaacademy.org/wpcontent/uploads/2014/10/21st_century_skills.p $\underline{d f}$

Bybee, W. R. (2013). The Case for STEM Education: Challenges and Opportunities. Arlington, VA: NSTA Press. 
Billstein, R., \& Williamson, J. (2007). Middle School Math Thematics The Stem Project. In Evanston: McDougal Littel.

Corlu, M. S., Capraro, R. M., \& Capraro, M. M. (2014). Introducing STEM education: Implications for educating our teachers in the age of innovation. Egitim ve Bilim, 39 (171), 74-85.

Geddes, S. J. (2004). Mobile learning in the 21st century: benefit for learners. Knowledge Tree e-journal, 30 (3), 214-228.

Gonzalez, H. B., \& Kuenzi, J. J. (2012). Science, technology, engineering, and mathematics (STEM) education: A primer. Washington, DC: Congressional Research Service, Library of Congress.

Hanover Research. (2011). K-12 STEM education overview.

Irmita. (2018). Pengembangan modul pembelajaran kimia menggunakan pendekatan science, technology, engineering and mathematic (STEM) pada materi kesetimbangan kimia. Jurnal Pendidikan Kimia, 2 (2), 27-37. https://doi.org/10.19109/ojpk.v2i2.2665

Leonard \& Wibawa, B. (2020). Development of teacher research competency training system in Indonesia: A need analysis. Universal Journal of Educational Research, 8 (5), 2064-2070. http://doi.org/10.13189/ujer.2020.080544

Mayasari, T., Kadarohman, A., \& Rusdiana, D. (2014). Pengaruh pembelajaran terintegrasi science, technology, engineering, and mathematics (STEM) pada hasil belajar peserta didik: Studi meta analisis. Prosiding Semnas Pensa VI "Peran Literasi Sains", 371-377.

McDonald, M. A., Mathews, D., \& Strobel, K. (2000). Understanding sequences: A tale of two objects. Research in Collegiate Mathematics Education, IV (8), 77-102.

McKenney, S., \& Reeves, T. C. (2014). Educational design research. In Handbook of research on educational communications and technology, 131-140. Springer, New York, NY.

Musahrain, M., Suryani, N., \& Suharno, S. (2017). Pengaplikasian mobile learning sebagai media dalam pembelajaran. In Seminar Nasional Teknologi Pendidikan 2017. Sebelas Maret University. https://doi.org/10.1007/BF00350647

Nessa, W., Hartono, Y., \& Hiltrimartin, C. (2017). Pengembangan buku siswa materi jarak pada ruang dimensi tiga berbasis science, technology, engineering, and mathematics (STEM) problem-based learning di kelas X. Jurnal Elemen, 3 (1), 1-14.

Nurdin, L. (2012). Analisis Pemahaman Siswa tentang Barisan Berdasarkan Teori APOS (Action, Process, Object and Scheme).

National Science Teacher Association. (2011). Quality science education and 21st-century skills. Accessed from http://www.nsta.org/about/positions/21stcentury.aspx

Permendikbud. (2018). Perubahan Atas Peraturan Menteri Pendidikan Dan Kebudayaan Nomor 24 Tahun 2016 Tentang Kompetensi Inti Dan Kompetensi Dasar Pelajaran Pada Kurikulum 2013 Pada Pendidikan Dasar Dan Pendidikan Menengah.

Prahmana, R. C. I. (2017). Design Research (Teori dan implementasinya: Suatu pengantar). Depok : Rajawali Pers.

Roberts, A., \& Cantu, D. (2012, June). Applying STEM instructional strategies to design and technology curriculum. In PATT 26 Conference; Technology Education in the 21st Century; Stockholm; Sweden; 26-30 June; 2012 (No. 073, 111-118). Linköping University Electronic Press.

Rustaman, N. Y. (2016). Pembelajaran sains masa depan berbasis STEM education. In Prosiding Seminar Nasional Biologi Edukasi (Vol. 1, 1-17). Padang.

Simanjuntak, D. (2013). Peranan teknologi informasi dan komunikasi dalam kurikulum 2013. Jurnal Pendidikan Penabur, 78-87. 
Subramaniam, M. M., Ahn, J., Fleischmann, K. R., \& Druin, A. (2012). Reimagining the role of school libraries in STEM education: Creating hybrid spaces for exploration. The Library Quarterly, 82 (2), 161-182. https://doi.org/10.1086/664578

Utami, T. N., Jatmiko, A., \& Suherman, S. (2018). Pengembangan modul matematika dengan pendekatan science, technology, engineering, and mathematics (STEM) pada materi segiempat. Desimal: Jurnal Matematika, 1 (2), 165-172. https://doi.org/10.24042/djm.v1i2.2388

Widoyoko, E. P. (2010). Evaluasi Program Pembelajaran. Yogyakarta: Pustaka Pelajar.

Winarni, J., Zubaidah, S., \& Koes, S. (2016). STEM: apa, mengapa, dan bagaimana. Prosiding Semnas Pend IPA Pascasarjana UM, 1, 976-984.

Zulkardi. (2006). Formative Evaluation: What, Why, When, and How. Online, https://www.oocities.org/zulkardi/books.html 